\title{
SOME ETHICAL ISSUES IN THE PRENATAL DIAGNOSIS OF SICKLE CELL ANAEMIA
}

\author{
Joseph O. Fadare \\ Department of Medicine, Kogi State Specialist Hospital, Lokoja, Kogi State, Nigeria
}

Corresponding author:.

Dr. Joseph O. Fadare

Department of Medicine, Kogi State Specialist Hospital, Lokoja, Kogi State, Nigeria

Tel: +234- 8138048127

Email: jofadare@gmail.com

\begin{abstract}
Sickle cell anaemia (SCA) is the most common form of haemoglobinopathy in Nigeria affecting $1-3 \%$ of the population and it is associated with physical, psychosocial and emotional suffering. Prenatal diagnosis (PND) and genetic counseling are ways of preventing the spread of the disease; however these means of prevention are associated with many ethical dilemmas. Ethical issues discussed in this paper include the safety of the procedures used in obtaining tissue sample for prenatal diagnosis, abortion of affected fetuses and the question of genetic selection. Finally, the ethical implications of genetic counseling and issues relating to the principle of justice in healthcare are highlighted.
\end{abstract}

Keywords: Sickle cell anaemia, prenatal diagnosis, ethical issues

\section{INTRODUCTION}

Sickle cell anaemia (SCA) is the predominant haemoglobinopathy in Nigeria affecting about 1-3\% of the Nigerian population ${ }^{1}$. The disease is associated with a lot of physical, psychosocial, emotional and financial burden and could lead to a disruption of family life ${ }^{2}$. Studies from Nigeria have shown different levels of perception of the disease among family members $^{3}$ and caregivers ${ }^{4}$ and among enlightened members of the public ${ }^{5}$. The disease runs a chronic course but is now curable using gene therapy and bone marrow transplantation ${ }^{6}$. However, these novel means of therapy are not yet widely available in developing countries like Nigeria hence the importance of preventive measures in these settings. The availability of prenatal diagnosis (PND) for the disease has opened a window of opportunity for expectant couples to have information about the haemoglobin $\mathrm{Hb}$ genotype of their unborn child. This gives them the option of termination of the pregnancy in case of positive result and to prepare them psychologically, financially and medically for the arrival of the new child when abortion is not an option. It is interesting to note that many of the respondents in the studies cited earlier are aware of this possibility even though the test is not widely available in Nigeria (as at the time of the study) $)^{3,4,5}$. Studies from Europe have shown that using prenatal diagnosis PND has led to a reduction in the incidence of some genetic disorders like cystic fibrosis and haemoglobinopathies ${ }^{7,8}$. Prenatal diagnosis is usually carried out using either chorionic villus sampling (CVS) or amniocentesis and the samples taken have DNA analysis done on them. Both procedures are invasive with CVS being done between the 10 th and 12 th week of pregnancy while amniocentesis is usually carried out later (between the 14th and 20th week). Prenatal testing for genetic conditions generally is associated with a lot of ethical concerns and sickle cell anaemia is not an exception. The aim of this work is to discuss some of these issues especially in the context of a developing country like Nigeria.

\section{ETHICAL ISSUES}

The issue of safety of the procedures used for PND is worth mentioning first. Though they are found to be relatively safe, there is still a chance of a miscarriage following chorionic villus sampling and amniocentesis (worse with CVS and usually multi-factorial) ${ }^{9,10}$. Abortion of the affected fetus is regarded as a component of PND in most cases. In the case of the fetus having the SS genotype, the ethical question arises whether to have an abortion or to keep the pregnancy. The decision whether to terminate a pregnancy based on a positive result is usually a difficult one that involves religious, psychosocial and cultural considerations ${ }^{1}$.

Another reason why the abortion of an affected fetus may not be accepted is because of the risk of complications mainly due to lack of reliable and safe health care practices in developing countries. Even when abortion is legal in the local context, the question whether it is right to terminate an innocent life is still a much debated issue. If on the other hand, a decision is made to keep the pregnancy, the question whether it is right or not to bring a child with a disease condition that causes so much suffering to the world. Utilitarians 
would argue that it is more cost effective to abort the affected fetuses as this will reduce on the long run the socio-economic and emotional consequences of the disease. Bringing up the question of cost-effectiveness and life of patients would be looked at in many developing countries like Nigeria as being cold and inhuman, but the reality of scarcity of resources and rationing of health care resources is there for all to see. The introduction of pre-implantation genetic diagnosis (PGD) in developed countries would seem to have put the controversial issue of termination of affected pregnancy at rest as only "genetically healthy" embryos will be transferred to the uterus. The practice itself is laden with its' own ethical dilemmas relating to: the moral status and destruction of embryos, tendencies for eugenic practices (selection of particular traits in the embryo), the possibility of long term complications from the procedure and distributive justice issues ${ }^{11}$. Opponents of these prenatal or preimplantation tests would also argue that SCA is now becoming a chronically manageable disease with increase in life expectancy and quality of life of patients hence there is no reason for these investigations.

Some people would argue that using a prenatal diagnosis for SCA would lead to a systematic elimination of the genetic mutation from the population. Could this be called a form of eugenics? The author definitely does not think so as the choice here is not about specific traits that are desired in a child but having a child free of a particular genetic disorder. The right to know is a fundamental right of the couple hence carrying out a PND for SCA actually empowers the couple to plan for the new child (if they decide to keep the pregnancy - if SS genotype) and gives them peace of mind (if AS or AA genotype). This is the autonomous choice of the couple, a right to decide what is acceptable to them. There is also the risk of pressure being put on the couple directly or indirectly by the society to have prenatal diagnosis done because of the availability of the tests (the so called technological imperative). This could lead to affected couples being blamed for not making use of the tests to avoid having children with sickle cell disease.

The scope of genetic counseling offered by health care workers (clinical geneticist, haematologist, nurse or obstetrician) has a lot of ethical implications. Several studies have clearly shown that genetic counseling is considered as one of the best ways of controlling the disease $^{12}$. As usual with genetic counseling a "nondirective" and "client-centered" form of counseling is preferred. This form of counseling entails disclosure of genetic risk information necessary for the clients to make an informed decision without direct or indirect advice from the counselors. But the question whether it is possible to be absolutely non-directive in counseling is one that is generating a lot of debates among bioethicists and geneticists ${ }^{13}$. How can one ignore his or her own intuition and sense of morality when confronted with challenging situations? Is it possible for a counselor who is a practicing Roman Catholic to be value- neutral when discussing abortion as an option after PND? Counseling for SCA is even more problematic because of the variability in severity of the disease among different patients: while some live fairly crises-free lives for long (50-60yrs), some die during childhood or adolescence. So how do we know which form of the disease the unborn child is going to develop?

Finally, the principle of justice in health care requires that access to PND be fair and equitable. This is definitely not so because of intra-country and intercountry disparity in access to PND; many people requiring prenatal diagnosis for SCA may not have access to it because of lack of the service in their environment or inability to pay for the services. This is particularly common in developing countries of SubSaharan Africa where payment for health care is still mainly "out of pocket" 14 . This problem of access to prenatal diagnosis remains one of the major impediments to the control of SCD in developing countries.

\section{CONCLUSION}

This review article has clearly shown the ethical dimensions of prenatal diagnosis in the setting of a developing country like Nigeria. It is important for health care providers to be conscious of these issues especially when providing service to clients. There is also a need to build capacity in the area of genetic counseling as a means of controlling the spread of sickle cell anaemia.

\section{REFERENCES}

1. Durosinmi M.A., Odebiyi A.I., Akinola N.O., Adediran L.A., Aken'Ova Y., et al. Acceptability of prenatal diagnosis of sickle cell anaemia by a sample of the Nigerian population. Afr J Med Sci 1997; 26:55-58.

2. Ohaeri J.U., Shokunbi W.A. Psychosocial burden of sickle cell disease on caregivers in a Nigerian setting. J Natl Med Assoc 2002; 94:1058-1070

3. Durosinmi M.A., Odebiyi A.I., Adediran I.A., Akinola N.O., Adegorioye D.E., et al. Acceptability of prenatal diagnosis of sickle cell anaemia (SCA) by female patients and parents of SCA patients in Nigeria. Soc Sci Med 1995; 41:433-436. 
4. Adeyemi A.S., Adekanle D.A. Knowledge and attitude of female health workers towards prenatal diagnosis of sickle cell disease. Niger J Med 2007; $16: 268-270$

5. Moronkola O.A., Fadairo R.A. University students in Nigeria: knowledge, attitude toward sickle cell disease, and genetic counseling before marriage. Int Q Community Health Educ. 2006-2007; 26:8593

6. Misaki W. Bone marrow transplantation (BMT) and gene replacement therapy (GRT) in sickle cell anemia. Niger J Med 2008; 17:251-256

7. Cunningham S., Marshall T. Influence of five years of antenatal screening on the paediatric cystic fibrosis population in one region. Arch Dis Child 1998;78: 345-348

8. Cao A., Rosatelli M.C. Screening and prenatal diagnosis of the haemoglobinopathies. Baillieres Clin Haematol 1993; 6: 263-286

9. Papp C., Papp Z. Chorionic villus sampling and amniocentesis: what are the risks in current practice? Curr Opin Obstet Gynecol. 2003; 15:159-165.
10. Evans M.I., Wapner R.J. Invasive prenatal diagnostic procedures. Semin Perinatol. 2005; 29:215-218.

11. Cameron C., Williamson R. Is there an ethical difference between pre-implantation genetic diagnosis and abortion? J Med Ethics. 2003 ;29:9092

12. Gustafson S.L., Gettig E.A., Watt-Morse M., Krishnamurti L. Health beliefs among African American women regarding genetic testing and counseling for sickle cell disease. Genet Med. 2007; 9:303-310

13. Clarke A. Is non-directive counseling possible? The Lancet, 1991; 338 :998-1001

14. Leive A., Xu K. Coping with out-of-pocket health payments: empirical evidence from 15 African countries. Bull World Health Organ. 2008; 86:849856 